\title{
5
}

\section{Judicial Dialogue in Action: Making Sense of the Risk of Absconding in the Return Procedure}

\author{
MADALINA MORARU
}

\section{Introduction}

This chapter analyses the contribution of courts and judicial dialogue to the implementation of the 'risk of absconding,' ${ }^{1}$ which has proved to be one of the most problematic notions introduced by the Return Directive. ${ }^{2}$ The meaning of the 'risk of absconding' has been surrounded by confusion from the very start of the negotiations on the Return Directive. ${ }^{3}$ Initially, the European Commission's proposal for a Return Directive did not provide a definition of this notion. Instead, a definition was introduced in Article 3(7) following a compromise reached between the opposing views of the Commission, Council and Parliament. ${ }^{4}$ The compromise definition used a very broad phrasing and did not provide for a harmonised list of circumstances that could lead to finding a risk of absconding. According to the Return Directive, Member States are required only to provide for objective criteria in national laws. The number and content of 'objective criteria' is not harmonised at EU level; instead Member States have retained the power to set these circumstances. This freedom has been wrongly interpreted as being unrestricted by EU legal guarantees, so much so that certain Member States listed so many and broad circumstances that a risk of absconding would almost always

\footnotetext{
${ }^{1}$ See Art 3(7) of the Return Directive.

${ }^{2}$ Directive 2008/115/EC of the European Parliament and of the Council of 16 December 2008 on common standards and procedures in Member States for returning illegally staying third-country nationals [2008] OJ L348, 98.

${ }^{3}$ See also the 2017 European Migration Network (EMN) Report on the effectiveness of return in the EU Member States (hereinafter '2017 EMN Report') 3.

${ }^{4}$ See F Lutz and S Manashvili, 'Commentary on the Return Directive' in K Hailbronner and D Thym (eds), EU Asylum and Immigration Law, 2nd edn (Munich and Oxford, CH Beck and Hart Publishing, 2016) 693.
} 
be presumed to exist, ${ }^{5}$ thus endangering the effective fulfilment of the Directive's objectives. $^{6}$

The implementation of the risk of absconding has been a constant challenge for national authorities. ${ }^{7}$ The first problem consisted of partial domestic transposition of this concept, particularly during the first four years after the Directive's entry into force. ${ }^{8}$ Even when the notion was later on domestically transposed, administrative practices varied widely across the Member States in terms of: types of legal acts implementing the risk of absconding; scope of objective criteria on the basis of which a risk of absconding would be presumed; standards for the burden of proof; and the level of individual assessment that should be carried out before finding the existence of a risk of absconding. ${ }^{9}$ More recently governments have mentioned challenges to complying with the high standards imposed by national judicial authorities interpreting the notion of risk of absconding. ${ }^{10}$

Within this context of minimal harmonisation of the 'objective criteria', and arrogated unfettered Member States' powers to define them, national courts have been consistently seized with requests of clarification of the notion of risk of absconding. Domestic courts across the EU were faced with similar questions regarding the interpretation and application of the risk of absconding, namely: in what type of legal act should the risk of absconding be defined? What circumstances can be considered as objective criteria and how many objective criteria can be included within the risk of absconding definition? Is the existence of objective criteria sufficient to find a risk of absconding or other circumstances, and which ones should be taken into consideration in the assessment? What type of return-related measure should be chosen when a risk of absconding is identified? In addition to these questions, which the competent administrative authorities must also address, courts initially faced an additional challenge which results from their limited powers of review and remedy in immigration cases. Due to the fact that the Return Directive had not harmonised procedural aspects regarding the division of competences between courts and administration, nor the domestic judicial design over return proceedings, ${ }^{11}$ a varied configuration of courts with different reviewing and remedial judicial powers had developed in the EU. ${ }^{12}$

\footnotetext{
${ }^{5}$ eg Italy, Netherlands, Slovenia; for more details, see section II.

${ }^{6}$ ie according to Art 1: effective return and respect of fundamental rights.

${ }^{7}$ According to Communication from the Commission to the Council and the European Parliament on EU Return Policy, COM(2014)0199 final (hereinafter '2014 EC Evaluation of the Implementation of the Return Directive'); P de Bruycker, M Moraru and G Renaudiere, 'Report on Effective Returns, and European Synthesis report on the Termination of Illegal Stay', REDIAL Research Report 2016/01, 17 et seq, available at https://cadmus.eui.eu/handle/1814/41206.

${ }^{8}$ Namely, not all Member States transposed the Return Directive, and in particular Art 3(7) of the Directive; see 2014 EC Evaluation of the Implementation of the Return Directive, ibid, 12.

${ }^{9}$ According to data collected within the REDIAL Project; see more in the national reports available at http://euredial.eu/.

${ }^{10}$ According to the 2017 EMN Report (n 3$) 3$.

${ }^{11}$ These procedural aspects commonly fall under the procedural autonomy of the Member States.

${ }^{12}$ For an accurate mapping of the judicial competences in return procedures across the EU, see D Kosar and A Blisa, 'Scope and Intensity of Judicial Review: Which Power for Judges Within the Control of Immigration Detention?' Chapter 8 in this volume.
} 
This has contributed to a divergent practice, especially as regards the choice of different types of return measures being adopted for similar risks of absconding. ${ }^{13}$ This varied judicial design added another source for divergent interpretation and implementation of the risk of absconding, ${ }^{14}$ at least up until the CJEU delivered its judgment in the Mahdi case. ${ }^{15}$

This chapter argues that courts, with the help of vertical and transnational judicial dialogue, have played a crucial role in clarifying key aspects of the EU law notion of 'risk of absconding. For instance, multidimensional judicial dialogue has widely contributed to the legality and transparency of 'objective criteria' (ie definition in national legislation) and establishing individual assessment as a mandatory requirement for establishing the appropriate return measure when a risk of absconding is present. On the other hand, the number and content of 'objective criteria' have mostly remained those existent before the entry into force of the Directive. ${ }^{16}$ On this issue, the domestic courts' approach has been quite conservative, as they neither addressed a preliminary reference to the CJEU asking for guidelines on how to interpret the requirement of 'objective criteria', nor disapplied national legislation providing numerous objective criteria that would revert the Directive mandatory order of return stages. This chapter thus argues that more efforts are needed both from domestic judiciaries and legislatures to remedy the domestic lists including numerous objective criteria, especially those originating from before the entry into force of the Directive, ${ }^{17}$ along the lines of the CJEU jurisprudence.

The chapter builds this argument in two main sections. First, it will map out the main problems in the implementation of the EU notion of the 'risk of absconding' in section II. Second, it will analyse the contribution of the courts and judicial dialogue in tackling these various problems in section III. ${ }^{18}$ The chapter concludes by finding that, through the use of judicial dialogue (vertical, transnational and horizontal), national courts have ultimately strengthened their position vis-a-vis domestic administrative authorities in an attempt to ensure the effet utile of the Return Directive. Seeing their immigration powers gradually constrained by judicial principles, domestic governments are increasingly challenging the judiciary's understanding of immigration issues and, thus, implicitly, also the legitimacy of the judicial scrutiny of the Return Directive's

\footnotetext{
${ }^{13}$ See, in particular, Chapters 1, 6 and 11-14 in this volume.

${ }^{14}$ See the results of the comparative analysis presented by M Moraru and G Renaudiere, REDIAL Research Report 2016/05, available at http://euredial.eu/.

${ }^{15}$ Case C-146/14 Mahdi ECLI:EU:C:2014:1320.

${ }^{16}$ eg Spain (see Chapter 1 in this volume), Netherlands (G Cornelisse and J Bouwman, 'REDIAL National Synthesis Report on Termination of Illegal Stay', 2-4, available at http://euredial.eu/ docs/publications/national-synthesis-reports/NETHERLANDS.pdf) and Slovenia (REDIAL Research Report 2016/01 (n 7) 17 et seq).

${ }^{17}$ See, in particular, Spain, according to CG Rotaeche, 'Return Decisions and Domestic Judicial Practices: Is Spain Different?', Chapter 2 in this volume.

${ }^{18}$ The case-law used for this chapter comes from the REDIAL database and other chapters in this volume.
} 
administrative implementation. ${ }^{19}$ In addition, the Commission proposal for a Recast of the Return Directive puts forward highly challengeable proposals on the risk of absconding from the perspective of their compliance with judicially developed standards. ${ }^{20}$ A new Article 6 is proposed, which includes a non-exhaustive list of objective criteria, which are divided in two categories: rebuttable and indicative criteria, which challenge the foundational principle of individual assessment governing return proceedings. ${ }^{21}$ This very broad definition of the risk of absconding, including criteria contrary to the CJEU jurisprudence, ${ }^{22}$ has attracted heavy criticism from the Council of Europe's Human Rights Commissioner, the EU's Fundamental Rights Agency and OSCE. These institutions argued that the Commission-proposed definition of the risk of absconding is likely to lead to human rights violations without furthering other goals, such as facilitating the processing of asylum claims or promoting dignified returns. ${ }^{23}$ It is thus timely to question what are the red lines developed by European and domestic courts on the content and effects of the risk of absconding in return procedures, which should be respected at both EU and domestic level.

\section{Diagnosing the Implementation of the Risk of Absconding: Problems and their Sources}

The Return Directive defined the risk of absconding as 'existence of reasons in an individual case which are based on objective criteria defined by law to believe that a third-country national who is the subject of return procedures may abscond'. Notably, the definition includes two cumulative requirements: (1) an objective, general requirement ('objective criteria defined by law'), which must be defined in the laws of the Member States; and (2) a fact-based requirement

\footnotetext{
${ }^{19}$ See B Nagy, 'Restricting Access to Asylum and Contempt of Courts: Illiberals at Work in Hungary', 18 December 2017, OMNIA blog; 'Italy's Far-Right Interior Minister, Matteo Salvini, Escalates Attack on Judges', The Guardian, www.theguardian.com/world/2019/jun/06/salvini-steps-up-attacks-onitalian-judges-who-challenge-him; M Marmo and M Giannacopoulos, 'Cycles of Judicial and Executive Power in Irregular Migration' (2017) 5(1) Comparative migration studies 16; and 2017 EMN Report (n 4) 3.

${ }^{20}$ See Proposal for a Directive of the European Parliament and of the Council on common standards and procedures in Member States for returning illegally staying third-country nationals (recast) Brussels, COM(2018) 634 final 2018/0329 (COD) ('the Proposal').

${ }^{21}$ See proposed Art 6 . The 'individual assessment' is a mandatory requirement under both current version of the Return Directive (eg Recitals 10, 14, Arts 3(7), 7, 15) and recast version (eg Recitals 12, $13,17,19,24,28$, Arts 3(7), 7(2)).

${ }^{22}$ Such as: lack of documentation proving the identity, illegal entry into the territory of the Member States.

${ }^{23}$ See FRA Opinion - 1/2019 [Return], Vienna, 10 January 2019, 'The recast Return Directive and its fundamental rights implications, and the public statement of Council of Europe's Commissioner for Human Rights, Nils Muižnieks, www.facebook.com/CommissionerHR/posts/753609061481673; OSCE PA Ad Hoc Committee on Migration, 'Briefing on Effective and Humane Return Policy', 2 April 2019.
} 
('in an individual case'), whereby competent authorities - namely the administrative or judicial authorities - are required to examine on a case-by-case basis all the individual, specific circumstances that characterise each applicant's situation. ${ }^{24}$ Although this definition is a step forward compared to the initial proposal of the Commission which did not include any definition of the risk of absconding, it leaves key questions unanswered: in particular, the type and number of objective criteria, and the level of certainty required to find a risk of absconding. In practice, the Member States have arrogated unfettered powers to define these aspects, often overlooking key EU legal guarantees introduced by Article 3(7), the preamble of the Directive and general EU legal principles, such as proportionality and rule of law.

This section argues that six common issues have transnationally developed in the domestic implementation of the risk of absconding: (1) delayed domestic transposition of the notion of 'risk of absconding'; (2) incorrect transposition of the notion of 'law' solely in administrative practice or acts which lack the essential requirements of legality as defined by the ECtHR and CJEU; ${ }^{25}$ (3) a broad list of objective criteria establishing a risk of absconding in almost all cases of irregularity; (4) inclusion of challengeable circumstances, such as illegal stay, entry, lack of documentation and financial resources as objective criteria for finding a risk of absconding; (5) the automatic assumption of a risk of absconding solely based on existence of one of the objective criteria; and (6) a preference for establishing forced return measures over less coercive measures when a risk of absconding is identified.

These practices of incorrect and inconsistent domestic implementation of the risk of absconding have mostly resulted from a combination of factors, such as: the minimum harmonisation introduced by the Directive as regards the definition of the risk of absconding, which was wrongly interpreted by the Member States as leaving them unfettered powers of regulation; the persistent resistance of the Member States to adapt their return procedures to the common procedure established by the Directive; the incorrect implementation of key principles guiding the entire return procedure, such as individual assessment, proportionality and fair procedures; and limited domestic judicial scrutiny and remedial powers in return proceedings.

First, several Member States have long delayed the transposition of the risk of absconding in their domestic laws, ${ }^{26}$ and some still do not provide a legal definition of the risk of absconding within the scope of return proceedings. ${ }^{27}$ Similar to other specific notions, such as 'return decision' and pre-removal 'detention',

\footnotetext{
${ }^{24}$ See also AG Opinion in the Al Chodor case, ECLI:EU:C:2016:865, points 59 and 60.

${ }^{25}$ ie precision, transparency, foreseeability, offers of additional assurances in terms of external control of the discretion of the administrative and judicial authorities responsible for assessing the risk of absconding.

${ }^{26}$ Austria in 2014, Czech Republic in 2015, Germany in 2016; more detailed information will follow in section III.

${ }^{27}$ eg Malta, according to data available up until January 2019.
} 
the risk of absconding was transposed with delays due to the reticence of certain Member States to adapt their immigration procedures to the specific terminology introduced by the Return Directive. ${ }^{28}$ Instead, some of the Member States retained their previous expulsion-related terminology or introduced broader concepts than the risk of absconding. ${ }^{29}$

Even when the Member States did transpose the risk of absconding at the domestic level, a second problem resulted from the fact that not all Member States defined the risk of absconding in a domestic 'law' in the sense of Article 3(7). Some Member States have provided a definition in administrative acts (eg Belgium, Hungary and the Netherlands), instead of laws enacted by parliament or, even when defined in domestic law, additional objective criteria were followed in administrative practice. ${ }^{30}$ In fact, the legislative definition of the risk of absconding, as ground for return-related measures, has been introduced quite recently in certain jurisdictions, following courts' pronouncements reached on the basis of judicial dialogue. ${ }^{31}$ The main issue of defining the risk of absconding in administrative practice is the lack of clarity, precision, foreseeability and transparency of such practices for the affected individuals. Furthermore, administrative acts cannot fulfil the essential requirements of domestic implementation, since the separation-of-powers requirement inherent in the rule of law is not fulfilled in this case. That is, the same authority entrusted to apply the risk of absconding has also been the author of the definition, which raises concerns regarding the respect of the rule of law. ${ }^{32}$

Even if the risk of absconding was transposed in a national law adopted by parliament, a third problem developed, namely that of broad definition of the objective criteria requirement. Since neither Article 3(7) nor any other provision of the Directive prescribes a list of objective criteria, Member States remain free to set their own lists, which has led in practice to the adoption of domestic lists of varied lengths. While certain factors are generally accepted as objective criteria by a majority of Member States, ${ }^{33}$ additional criteria have been included in national legislation or followed in practice. Moreover, the compatibility of certain

\footnotetext{
${ }^{28}$ For instance, the term 'expulsion' is still commonly used by several Member States instead of 'return' (eg Austria and Spain). 'Public custody' is still favoured by several Member States over 'preremoval detention' (eg France and Romania), according to REDIAL National Reports on Austria, France, Romania and Spain, available at http://euredial.eu/publications/national-synthesis-reports/; see also Chapters 2 and 14 in this volume.

${ }^{29}$ Spanish Immigration Act 4/2000 (Art 62) does not refer to the risk of 'absconding' either. Rather, it refers to the risk of 'non appearance': 'non presentation due to lack of residence or of identification documents'. See the REDIAL Report on Pre-Removal Detention in Spain.

${ }^{30}$ eg Austria; see REDIAL Report on Pre-Removal Detention in Austria.

${ }^{31}$ Austria, Germany and the Czech Republic introduced a legislative definition of the risk of absconding after 2014, see more in section III.A.

${ }^{32}$ See n 24 and CJEU judgment in Case C-528/15 Al Chodor ECLI:EU:C:2017:213, para 44.

${ }^{33} \mathrm{Such}$ as refusal to cooperate in the identification process; use of false documentation or the deliberate destruction of documents; failing repeatedly to report to the relevant authorities; explicit expression of intent of non-compliance; existence of conviction for criminal offence; non-compliance with existing entry ban; and the violation of a return decision; see REDIAL Research Reports 2016/01 and 2016/05 (nn 8 and 15), and 2017 EMN Report (n 3) 28-29.
} 
objective criteria with the Return Directive is highly questionable. For instance, the following circumstances were listed in 2018 as objective criteria by different Member States: illegal entry or stay (eg Estonia, France, Romania, Slovenia, Spain); lack of residence permit (eg Slovakia); lack of passport of other equivalent identification documents (eg Bulgaria, Italy); lack of sufficient financial resources (eg Italy, the Netherlands). ${ }^{34}$ Other Member States have significantly expanded the scope of the objective criteria, by including a long list of objective criteria, in some cases amounting to as many as 15 circumstances for finding a risk of absconding (eg Italy, the Netherlands and Slovenia). ${ }^{35}$ Such lengthy lists raise issues of compatibility with the principles of individual assessment, legality, proportionality and exceptionality of the risk of absconding which cannot be equated with the notion of irregularity. Certain Member States included among the objective criteria circumstances clearly prohibited by the Directive, as interpreted by the CJEU, such as illegal entry and stay. ${ }^{36}$ Furthermore, other circumstances, such as lack of financial resources or of identity documents, would cover many irregularly present third-country nationals without necessarily indicating a risk of absconding, but only indicating the precarity or vulnerability of their situation. The practical result of these broad objective criteria is that of blurring the line between irregularity and risk of absconding, and reversing the logic and order set out by the Directive, namely of prioritising voluntary departure over all other forced forms of return.

A fourth problem, widespread among domestic authorities, was the automatic assumption of a risk of absconding based on the existence of one of the objective criteria, without any individual assessment being carried out. Although Article 3(7) of the Return Directive requires an individual assessment as part of the definition of the risk of absconding, which means that no objective criteria can automatically lead to the finding of a risk of absconding, several Member States have nevertheless followed a practice of presumption of a risk of absconding when certain objective criteria were found to be present. ${ }^{37}$ Often mere illegal entry or stay led to an automatic conclusion of an existence of a risk of absconding. ${ }^{38}$ Grounds such as criminal convictions or suspicion of criminal conviction were commonly considered as falling under the 'risk of absconding' and could automatically lead to refusal of voluntary departure and ordering removal. ${ }^{39}$

\footnotetext{
${ }^{34}$ According to data available in 2018 collected within the framework of the REDIAL Project. The domestic lists of objective criteria have been amended several times by the Member States during the 10 years of the Directive's existence.

${ }^{35}$ See REDIAL Research Report 2016/05 (n 14).

${ }^{36}$ According to Recital 6 of the Directive's preamble. For instance, Italy, see A di Pascale, 'Can a Justice of the Peace Be a Good Detention Judge? The Case of Italy', Chapter 13 in this volume.

${ }^{37} \mathrm{eg}$ in Italy and the Netherlands; furthermore some objective criteria were considered in these countries as establishing a non-rebuttal presumption, see more in REDIAL Research Report 2016/01 (n 8) 18, and REDIAL Research Report 2016/05 (n 15) 15.

${ }^{38} \mathrm{See}$, in particular for Italy, the Reports cited in (n 39).

${ }^{39}$ Such as in Cyprus, Belgium, Spain, Germany (eg Administrative Court of Augsburg, Au 6 K 12.667, 16 January 2013), Malta (Immigration Appeals Board of Malta, judgment of 25 March 2013), see more in M Moraru and G Renaudiere, REDIAL Research Report 2016/02, 20.
} 
This automatic decision-making appears to be more present in those Member States that viewed themselves as transit countries. ${ }^{40}$ These practices are particularly worrying in Member States where administrative automaticity is backed up by a deferential domestic judiciary. ${ }^{41}$

Even when the objective and fact-based requirements were fulfilled by Member States, a fifth problem developed, namely that of different types of return measures being adopted for similar risks of absconding. This is possible due to the fact that the risk of absconding is provided by the Directive as a legal basis for five different return-related measures, thus raising the issue of gradation and demarcation of measures when a risk is identified. According to Article 7(3), in the case of a 'risk of absconding', the Member State may require the addressee of a return decision to fulfil one or more of the following obligations: (1) regular reporting to the authorities; (2) the deposit of an adequate financial guarantee; and/or (3) surrender of documents or the obligation to stay at a certain place. ${ }^{42}$ The purpose of imposing additional obligations pending voluntary departure is to allow a period of voluntary departure in cases which would not normally otherwise qualify for such treatment. If these obligations have been breached, or if it is considered that the imposition of these obligations will not dispel the risk of absconding, or in other limited circumstances, then the third-country national can receive a period shorter than seven days for voluntary departure or even be refused the period altogether. ${ }^{43}$ In the latter situation, but also where the obligation to return has not been complied with within the period for voluntary departure, Article 8(1) requires the Member State that has issued a return decision to carry out the removal by taking all necessary measures including, where appropriate, coercive measures, in a proportionate manner and with due respect for, inter alia, fundamental rights.

The last-resort measures that can be adopted when a risk of absconding is found are pre-removal detention and the prolongation of such detention. ${ }^{44}$ Although the Directive does provide in the preamble that 'voluntary return should be preferred over forced return and a period for voluntary departure should be granted', the assessment of the level of risk and thus of the necessary return measure to be adopted is left to domestic assessment. In practice, similar

\footnotetext{
${ }^{40}$ eg Czech Republic (see M Moraru and L Janku, 'Can Strategic Litigation Rescue Asylum Seekers' Fundamental Rights? in Utrecht Special Issue of International and European Law, forthcoming 2020) and Romania (according to discussions during the workshops organised within the REDIAL Project up until the end of 2016).

${ }^{41}$ See C Demetriou and N Trimikliniotis, 'Cypriot Courts, the Return Directive and Fundamental Rights: Challenges and Failures', Chapter 5 in this Volume, and di Pascale (n 36).

${ }^{42}$ See Art 7(3) of the Return Directive. Since this list is not exhaustive, many of the Member States had provided additional obligations that could be imposed during the voluntary departure period. See the list in the 2017 EMN Report (n 3) 31; U Brandl, 'Voluntary Departure as a Priority: Challenges and Best Practices', Chapter 3 in this volume.

${ }^{43}$ See Art 7(4).

${ }^{44}$ See Art 15.
} 
circumstances have not always led to the adoption of a similar return-related measure. For instance, the lack of a passport or residence permit was the legal basis for the adoption of certain obligations to be fulfilled during the voluntary departure period, ${ }^{45}$ while other Member States adopted a pre-removal detention order, without providing additional explanations for their specific choices of measures. ${ }^{46}$

Ultimately, divergent interpretations of the risk of absconding have derived also from the varied configuration of domestic judicial powers in return procedures. Administrative, civil and criminal courts have certain competences to assess the risk of absconding depending on the Member States' specific allocation of judicial competences and also of the specific return measure at issue. ${ }^{47}$ Take, for instance, the adoption and review of the pre-removal detention measure, which is subject to wide institutional diversity among Member States: a criminal judge is competent in Belgium and Spain and recently also in France, and criminal chambers in common courts in Poland; a civil judge is competent in Germany, which unlike in other jurisdictions also has the power to adopt pre-removal detention; a 'justice of the peace' (giudice di pace, a non-professional judge) is competent in Italy; administrative courts, with specialised chambers on immigration law, are competent in the Netherlands, Austria, Bulgaria (only within the Supreme Administrative Court) or specialised administrative courts (Sweden); and general courts are competent in Hungary. ${ }^{48}$ The nature of the competent courts not only influences the judges' ideologies, but also the extent of their judicial scrutiny powers vis-a-vis the administration, ${ }^{49}$ and their remedial powers. This varied European judicial design has to a certain extent contributed to the development of incoherent interpretation of the risk of absconding and remedies in cases of violations. ${ }^{50}$

In conclusion, the domestic implementation of the risk of absconding has suffered from delayed and incorrect transposition, resulting in a variety of domestic approaches regarding the number, content and nature of objective criteria. An additional challenge has been the diverse scope and intensity of domestic judicial scrutiny among the Member States. This has contributed to the adoption of varied

\footnotetext{
${ }^{45}$ eg in the Netherlands; see more in REDIAL Research Report 2016/01 (n 8) 20.

${ }^{46}$ In the case of Re Rita Kumah (Supreme Court, Civil Application no 198/2013, 29 November 2013), a Cypriot court found 'that detention is necessary for as long as there is a risk of absconding and there is a risk of absconding in this case because the applicant did not have a passport or a residence permit'. On the other hand, the Lithuanian Supreme Administrative Court has consistently held that this alone cannot be the basis for detention without carrying out an individual assessment (no A3219-858/2015, judgment of 22 July 2015).

${ }^{47}$ See more in Kosar and Blisa chapter in this edited volume (n 13).

${ }^{48}$ See REDIAL Research Report 2016/05, according to date available up until 2017.

${ }^{49}$ For instance, the Justice of Peace exercising the most limited judicial scrutiny powers, and the civil judge in Germany exercising the most extensive judicial scrutiny powers in return proceedings, see more in di Pascale (n 36) and J Bornemann and H Dörig, 'The Civil Judge as Administrator of Return Detention: the Case of Germany', Chapter 9 in this volume.

${ }^{50}$ See more in Kosar and Blisa (n 12).
} 


\section{Madalina Moraru}

return-related measures even though a similar risk of absconding was sometimes present. ${ }^{51}$ Moreover, questions regarding the determination of the concrete risk of absconding and its corresponding return measure were often solved by choosing the easy route of automaticity in presuming a risk of absconding. In this context, clarification of the content and effects of the risk of absconding, and its coherent interpretation, have been achieved by national courts influenced in their decisions by the CJEU, the ECtHR, or other foreign or domestic courts. In the following sections, the main outcomes of the multidimensional judicial dialogue on the implementation of the risk of absconding notion will be assessed.

\section{Judicial Dialogue in Action: Tackling Implementation Challenges}

The implementation of the risk of absconding offers the opportunity to test some of the claims made by this book, namely that judicial dialogue has contributed to maintaining a balance between the two seemingly conflicting objectives of the Return Directive, ie effective return and respect of fundamental rights; filling gaps left by the EU legislator and thus ensuring a coherent application of the Return Directive; and empowering national courts to control administrative decisionmaking, thus ensuring the rule of law. As shown above, domestic courts across the EU faced similar questions regarding the interpretation and application of the risk of absconding: in what type of legal act should the risk of absconding be defined? What circumstances can be considered as objective criteria and how many objective criteria can be included within the risk of absconding? Is the existence of objective criteria sufficient to find a risk of absconding or should other circumstances, and which ones, be taken into consideration in the assessment? What type of return-related measure should be chosen when a risk of absconding is identified? In addition to these questions, which the competent administrative authorities too had to address, courts face an additional challenge which results from their limited powers of review and remedy in immigration cases. As mentioned above, there are varied judicial configurations across the $\mathrm{EU}$, and domestic courts across the EU do not enjoy the same reviewing and remedial powers. This has led to divergent judicial decisions proliferating on similar issues regarding the implementation of the risk of absconding. For instance, in certain domestic jurisdictions, courts could not consider facts beyond those brought by the administration and third-country nationals, and could not substitute the administrative decisions with their own, but only annul the administrative decision if they found a manifest illegality in the administrative decision-making. ${ }^{52}$

\footnotetext{
${ }^{51}$ According to the case-law gathered in the framework of the REDIAL Project.

${ }^{52}$ See, for instance, Bulgaria: V Ilareva, REDIAL National Synthesis Report on Pre-Removal Detention, available at http://euredial.eu/docs/publications/national-synthesis-reports/BulgariaFB2.pdf.
} 
Faced with this wide array of challenges, domestic courts resorted to various judicial dialogue techniques in the search for interpretative inspiration, including: finding solutions to conflicting norms or jurisprudential opinions; shortening the time for judicial decision-making; and enhancing the quality of judicial analyses and persuasiveness of reasoning, which can be crucial tools to strengthen judicial legitimacy against opposition from the administration or legislature.

Surprisingly, Article 3(7), which defines the risk of absconding within the Return Directive framework, has not yet formed the subject of a preliminary ruling, although the Return Directive is the EU immigration law instrument with the highest number of preliminary rulings delivered by the CJEU, close to 30 in a period of 10 years. ${ }^{53}$ Nevertheless, the preliminary rulings delivered on other provisions of the Directive (eg scope of application, pre-removal detention), and on the notion of the risk of absconding as grounds for detention under the Dublin transfer procedure, ${ }^{54}$ have offered salient guidelines also for the interpretation of the risk of absconding in return procedures. In addition, transnational judicial dialogue, a relatively rarely used type of judicial dialogue by domestic courts, ${ }^{55}$ has proliferated among courts from continental legal systems in an attempt to clarify one of the requirements of the risk of absconding - 'defined by law'. This section analyses the contribution of courts and of the various types of judicial dialogue to the clarification of the objective and subjective requirements of the risk of absconding and its effects in practice.

\section{A. The Objective Requirement: Clarification of the Meaning of 'Defined by Law' - The Ripple Effect of Judicial Dialogue}

According to Article 3(7) of the Return Directive, the definition of the risk of absconding must fulfil two requirements, namely: including 'objective criteria' which are 'defined by law', which represents the objective requirement; and an individual assessment, which represents the subjective requirement. As previously mentioned, several Member States did not initially provide a definition of the 'risk of absconding' in their national legislations, but in administrative acts and jurisprudence (eg Czech Republic, Belgium, Malta, Austria, Greece). ${ }^{56}$ Germany used to be one of these countries, and did not define the 'risk of

\footnotetext{
${ }^{53}$ As of June 2019.

${ }^{54}$ Regulation (EU) No 604/2013 of the European Parliament and of the Council of 26 June 2013 establishing the criteria and mechanisms for determining the Member State responsible for examining an application for international protection lodged in one of the Member States by a third-country national or a stateless person [2013] OJ L180, 31.

${ }^{55}$ See M Bobek, Comparative Reasoning in European Supreme Courts (Oxford, Oxford University Press, 2013); by refugee courts in particular, see Guy S Goodwin-Gill and H Lambert, The Limits of Transnational Law: Refugee Law, Policy Harmonization and Judicial Dialogue in the European Union (Cambridge, Cambridge University Press, 2010).

${ }^{56}$ According to data available until 2014.
} 
absconding' in either return or Dublin transfers procedures until $2016 .{ }^{57}$ In spite of its previous reticence to refer to EU secondary law and relevant CJEU jurisprudence, the German Supreme Civil Court held that the legislature had failed to fulfil the requirements set out by the Return Directive, namely to expressly provide for objective criteria in domestic legislation, instead of relying on the definition of the risk of absconding provided by the law implementing the Dublin III Regulation. ${ }^{58}$ Following this judgment, the legislature amended section 2(14) of the Residence Act, which now includes concrete objective criteria to be taken into consideration within return procedures. ${ }^{59}$ Prior to this judgment, the same Court obliged, in 2014, the German legislature to implement correctly Article 2(n) of the Dublin III Regulation, by defining 'risk of absconding' in the sense of Article 28 of the Regulation in a statutory law. ${ }^{60}$ This judgment led to a cross-fertilisation of norms and judgments across the EU. This was possible due to the fact that the definition of the risk of absconding is identical under the Return Directive, Recast Reception Conditions Directive ${ }^{61}$ and Dublin III Regulation, ${ }^{62}$ and all three instruments legitimise the adoption of detention on the basis of the risk of absconding.

These two German judgments had ripple effects across other domestic jurisdictions which found similarly to the German Supreme Civil Court that the risk of absconding whether provided by the Dublin III Regulation or by the Return Directive had to be defined in separate national laws in order to lawfully be the ground for detention of third-country nationals. For instance, the Supreme Administrative Court of Austria, ${ }^{63}$ and then also a Czech regional court, found that detention of asylum seekers under the Dublin procedure on the basis of a risk of absconding that was not defined in a domestic law, but solely based on objective criteria set out in consistent administrative and jurisprudential practice, is invalid. The regional court in Ustí nad Labem used these judgments as well as additional comparative reasoning. Specifically, it also assessed foreign domestic legislation (ie Belgium, Italy, Hungary, Bulgaria and Slovakia) with the aim of establishing how other legislatures interpret the requirements of Articles 2(n) and 28 of the Dublin III Regulation. ${ }^{64}$ It found that the respective national laws contained a

\footnotetext{
${ }^{57}$ Up until the judgment of the German Supreme Civil Court, BGH, Decision of 18.2.2016 - V ZB 23/15, para 14 .

${ }^{58}$ See Decision of 18 February 2016 - V ZB 23/15.

${ }^{59}$ Provision 2(14) Aufenthaltsgesetz was amended and now lays down seven criteria establishing the risk of absconding. For more details, see Dörig and Bornemann (n 49).

${ }^{60} \mathrm{BGH}$, Decision of 26.6.2014 - V ZB 31/14, paras 28 et seq.

${ }^{61}$ See Art 8(3)(b) of Directive 2013/33/EU of the European Parliament and of the Council of 26 June 2013 laying down standards for the reception of applicants for international protection [2013] OJ L180, pp 96.

${ }^{62}$ See Art 28(2)

${ }^{63}$ See judgment of Administrative Court of Austria, Verwaltungsgerichtshof, 19 February 2015, no 2014/21/0075-5.

${ }^{64}$ Judgment of Regional court in Ústí nad Labem of 1 June 2015, no 42 A 12/2015-78 (available in Czech at: http://nssoud.cz/files/EVIDENCNI_LIST/2015/42A_12_2015_20150615085958_ prevedeno.pdf).
} 
definition of the relevant objective criteria for assessing the risk of absconding. Following a textual interpretation of these domestic legal provisions, the court emphasised that Member States are required to adopt domestic legislative provisions to define the risk of absconding under the Dublin III Regulation. The court remarked that the Czech legislator incorrectly considered Articles 2(n) and 28(2) of Dublin III Regulation as having direct applicability, since these provisions are an exception to the general rule that EU regulations do not require transposition into national law; therefore, as with Article 3(7) of the Return Directive, the notion of the risk of absconding has to be transposed in domestic legislation. The court then turned to the analysis of Article 129(1) of the Czech Aliens Act and found that it lacked the required list of objective criteria. Furthermore, the court found that objective criteria, such as mere irregular entry and residence, ${ }^{65}$ which were used by the Czech administration as sufficient objective criterion for detention under Dublin proceedings, were contrary to the Regulation's prohibition to detain 'for the sole reason that [the asylum seeker] is subject to the procedure established by this Regulation. ${ }^{6}$ It should be noted that Recital 6 of the Return Directive contains a similar prohibition of 'illegal entry and stay' as the sole legal basis for decisions being taken in return proceedings. The Czech regional court concluded that the detention order issued to the Al Chodor family was unlawful, and annulled the Foreigners Police decision to detain the family. ${ }^{67}$

The judgment delivered by the regional court in Ustí nad Labem in the $A l$ Chodor case is quite a remarkable example of judicial comparative reasoning, assessing the judgments of two foreign supreme courts interpreting the risk of absconding, in an attempt to find a uniform interpretation of the EU legal requirement of 'defined by law' that the risk of absconding in a Dublin transfer procedure has to fulfil. ${ }^{68}$ The first-instance court's heavy reliance on comparative reasoning might be explained by the fact that it was the first court in the Czech Republic to consider the legality of Czech detention orders on the basis of EU primary and secondary legal provisions. Another reason for the Czech court's creative reasoning could have been the sensitive political nature of the issue. In fact, the case challenged the legality of a government policy, which is traditionally seen as reserved to executive competences. ${ }^{69}$ Recourse to additional legal sources of interpretation could have strengthened the legitimacy of the regional court's judgment towards the executive.

\footnotetext{
${ }^{65}$ Illegal entry and residence are also prohibited as objective criteria by Recital 6 of the Return Directive preamble.

${ }^{66}$ See Art 28(1) of the Dublin III Regulation.

${ }^{67}$ For a detailed analysis of this case, see Moraru and Janku (n 40).

${ }^{68}$ See Z Kühn, The Judiciary in Central and Eastern Europe, Mechanical Jurisprudence in Transformation? (Leiden, Brill, 2011); GS Goodwin-Gill and H Lambert, The Limits of Transnational Law: Refugee Law, Policy Harmonization and Judicial Dialogue in the European Union (Cambridge, Cambridge University Press 2010).

${ }^{69}$ See Moraru and Janku (n 40).
} 
Nevertheless, this judicial interpretation did not convince all domestic courts. ${ }^{70}$ In the appeal lodged by the Foreigners Police against the judgment of the regional court in Ustí nad Labem, the Czech Supreme Administrative Court favoured a broader interpretation of the EU legal notion of 'law', which, in its view, could have included not only legislation, but also other sources of law, such as judicial and administrative practice. ${ }^{71}$ Nevertheless, having doubts about the correct interpretation of the notion of 'law', the Supreme Administrative Court addressed a preliminary question to the CJEU. The Court asked whether the absence of objective criteria in a national law leads to the inapplicability of Article 28(2) of the Dublin III Regulation. ${ }^{72}$

In establishing the meaning of 'law', the CJEU itself made use of judicial dialogue and referred to the ECtHR case-law for the purpose of identifying the requirements that the law must fulfil when establishing limitations to the right to liberty. ${ }^{73}$ The Court of Justice found that 'only a provision of general application' could meet these requirements. In agreement with the first-instance Czech court and national courts from other Member States cited by the Czech court, the CJEU found that 'settled case-law confirming a consistent administrative practice on the part of the Foreigners Police Section, such as in the main proceedings' does not meet the safeguards required by Article 6 of the EU Charter of Fundamental Rights, in particular protection against arbitrariness. Consequently, detention on the basis of a risk of absconding, where the objective criteria are not set in 'a provision of general application', cannot be based on Article 28(2) of the Dublin III Regulation. The CJEU clarified that administrative practice, even if consistent and confirmed by jurisprudence, does not fulfil these requirements. Therefore Member States that adopt detention of asylum seekers in the absence of a legal provision of general application are acting contrary to EU law.

While the CJEU preliminary ruling did not have any impact in the Czech Republic, since implementing legislation was adopted a few months after the referral, ${ }^{74}$ the $\mathrm{Al}$ Chodor preliminary ruling did generate positive spillover effect well beyond the Czech Republic, requiring all countries operating the Dublin system and the Return Directive to define the criteria for a risk of absconding in 'a provision of general application'. This requirement has generally

\footnotetext{
${ }^{70}$ eg see Judgment of the Regional Court in Brno, 11 August 2015, no 33 A 40/2015-32.

${ }^{71}$ Provided that they possess the 'substantive' qualities of precision, foreseeability and accessibility as required by Art 5(1)(f) ECHR.

${ }_{72}$ Decision of the Czech Supreme Administrative Court on the suspension of national proceeding and lodging a preliminary reference to the CJEU of 24 September 2015, no 10 Azs 122/2015-88 (available in Czech at: http://nssoud.cz/files/SOUDNI_VYKON/2015/012210Azs_1500088_20150924125155_ prevedeno.pdf).

${ }^{73}$ Specifically, compliance with strict safeguards, namely the presence of a legal basis, clarity, predictability, accessibility and protection against arbitrariness, see Case C-528/15 Al Chodor ECLI:EU:C:2017:213, para 40.

${ }^{74}$ A legislative proposal was approved by the Parliament on 11 November 2015, and came into force on 15 December 2015.
} 
been interpreted at the domestic level as requiring definition in a domestic law. Following this judgment, the French Court of Cassation ${ }^{75}$ and the Administrative Court of Slovenia ${ }^{76}$ annulled detention orders issued within Dublin proceedings due to lack of domestic legislation defining the 'risk of absconding. These courts cited the Al Chodor preliminary ruling as an authoritative source for their decision to find administrative detention of asylum seekers subject to Dublin procedure unlawful. Furthermore, the Al Chodor judgment also triggered a process of legislative codification of the 'risk of absconding' in the United Kingdom, Belgium and Cyprus, ${ }^{77}$ and reinforced the findings of certain domestic courts that the risk of absconding, both in Dublin and return procedures, needs to be defined in legal provisions of general application, such as laws. ${ }^{78}$

The cases discussed here involved numerous judicial interaction techniques which led to cross-fertilisation of norms and judgments touching on the interpretation of the risk of absconding. For the purpose of clarifying whether the risk of absconding should be defined in a law or also in administrative practice, domestic courts have resorted to comparative reasoning, transnational judicial dialogue, preliminary reference and disapplication of national administrative practices in favour of a direct application of the Return Directive. Foreign and CJEU judgments empowered domestic courts to strengthen the rule of law in immigration matters by striking down non-transparent and arbitrary administrative decision-making.

\section{B. The Objectivity Requirement - Clarification of the Content and Number of Objective Criteria}

Article 3(7) of the Return Directive does not provide a common EU list of objective criteria, or an explanation of what and how many criteria a Member State could include as part of the definition of the risk of absconding. Certain Member States took advantage of the abstract definition of the 'risk of absconding', and provided for a catch-all list of objective criteria, leading to very few situations falling outside the scope of the risk of absconding. ${ }^{79}$ Several criteria introduced by Member States appear to be irrelevant to the assessment of a risk of absconding

\footnotetext{
${ }^{75}$ See Cour de Cassation, judgment no 1130 of 27 September 2017 [Pourvoi n 17-15.160]. For a detailed commentary on the judgment, see Marie-Laure Basilien-Gainche, 'The French Suite. The Effect of Al Chodor on the Detention of Asylum Seekers for the Purpose of a Dublin Transfer', blog post available at www.asylumlawdatabase.eu/en/journal/french-suite-effect-al-chodor-detention-asylumseekers-purpose-dublin-transfer.

${ }^{76}$ Administrative Court, Decision I U 1102/2016, 29 July 2016. The authorities applied by analogy the objective criteria provided for the definition of the risk of absconding as ground for pre-removal detention.

${ }^{77}$ See AIDA Update on the implementation of the Dublin III Regulation in 2018, available at http:// www.asylumineurope.org/sites/default/files/aida_2018update_dublin.pdf.

${ }^{78}$ See BGH, Decision of 18.2.2016 - V ZB 23/15, para 14.

${ }^{79} \mathrm{See}$, in particular, the practices reported in France, Italy, Netherlands and Slovenia, in REDIAL Research Report 2016/05 (n 14).
} 
(eg lack of financial resources, ${ }^{80}$ payment of large amounts of money to smugglers for the purpose of illegally entering the territory of Member States) ${ }^{81}$ Other problematic criteria, such as illegal entry and stay, continued as sufficient legal grounds for pre-removal detention. ${ }^{82}$

Member States have varied lists of objective criteria. Some of these lists are extensive, including numerous circumstances as objective criteria, whereas others include catch-all objective criteria (eg illegal entry or stay, or a criminal record). In certain jurisdictions which provide an exhaustive list of objective criteria, it suffices to satisfy a single criterion from this list to establish a risk of absconding and consequently to justify the adoption of pre-removal detention (eg Italy and Netherlands ${ }^{83}$ ). However, Article 3(7) of the Return Directive read in conjunction with Recital 6 requires that 'decisions taken under this Directive should be adopted on a case-by-case basis and based on objective criteria'. This implies that even when such objective criteria are set in national legislation, there can be no general presumption of the existence of the risk of absconding. Instead, individual situations and circumstances must additionally be taken into consideration. However, the individual assessment obligation was not included in the domestic legislation of all EU Member States. Thus competent administrative and judicial bodies could have found a risk of absconding once one of the objective criteria was found to exist. ${ }^{84}$

So far, the CJEU has not had the opportunity to interpret the 'objective criteria' requirement within the framework of return procedures. Nevertheless, domestic courts may find inspiration in the Jawo judgment, where the CJEU had to interpret the notion of 'objective criteria' within the framework of Dublin transfer proceedings. ${ }^{85}$ In this case, any absence of the third-country national from his or her allocated accommodation without prior notification to the competent national authorities was found to entitle domestic authorities to presume a risk of absconding, but only if they had fulfilled their obligation to inform the thirdcountry national of his or her obligation to notify the absence from or change in accommodation.

The Jawo as well as other preliminary rulings delivered by the CJEU in the field of the Return Directive confirm the mandatory nature of the individual assessment requirement, governing all stages of the return procedure. ${ }^{86}$ So far, the CJEU

\footnotetext{
${ }^{80}$ For instance, Italy, A di Pascale, REDIAL National Report on Pre-Removal Detention, http:// euredial.eu/publications/nationalsynthesis-reports.

${ }^{81}$ eg Germany; see Bornemann and Dörig (n 49).

${ }^{82}$ eg Italy, France, Slovenia, Romania, Spain and Slovakia; see REDIAL Research Report 2016/05 (n 9) 14.

${ }^{83}$ On the Netherlands, see G Cornelisse and J Bouwman, REDIAL Synthesis Report, first package (n 16) $2 \mathrm{ff}$.

84 ibid.

${ }^{85}$ Case C-163/17 Jawo ECLI:EU:C:2019:218.

${ }^{86}$ Case C-61/11 PPU El Dridi ECLI:EU:C:2011:268, para 39; Case C-430/11 Sagor EU:C:2012:777, para 41; Mahdi (n 15) para 70; Opinion of AG in Case C-290/14 Celaj ECLI:EU:C:2015:285, points 29 and 49.
} 
rejected a refusal of voluntary departure based on an automatic finding of a risk to public policy solely on the basis of suspicion that a third-country national has committed a criminal offence or an established criminal offence. ${ }^{87}$ The lack of identity documents was rejected as sole ground for a risk of absconding that could legitimise the prolongation of pre-removal detention. ${ }^{8}$ On the basis of the CJEU jurisprudence and discussions during the elaboration of the Return Directive, it can be inferred that the risk of absconding shall not automatically be deduced from the mere fact that a third-country national is illegally staying on the territory of a Member State. ${ }^{89}$

Relying on the Return Directive and the relevant CJEU jurisprudence, national courts from several Member States have started to reverse the practice of the administrative authorities, and reinterpreted flawed national legislation in line with EU law. ${ }^{90}$ Other domestic courts have taken a firmer position, rejecting reliance on the absence of established identity and documents. The Lithuanian Supreme Administrative Court has consistently held that this alone cannot be the basis for detention without carrying out an individual assessment. ${ }^{91}$ The Swedish Supreme Migration Court refused to consider a refusal of voluntary departure (an objective ground for pre-removal detention under Swedish legislation) as indicating a risk of absconding sufficient to justify a detention order. ${ }^{92}$

Although several supreme and regional courts used the individual assessment as a parameter of legality for the risk of absconding directly on the basis of the Return Directive, the general proliferation of this approach among domestic judiciaries came only after the CJEU consistently recognised the mandatory nature of the individual assessment throughout the return procedure, and indirectly rejected certain circumstances as objective criteria. This is the case of the French courts, which although they had traditionally allowed a wide margin of discretion in decision-making to the administration, gradually started to use individual assessment as a parameter of legality for return measures adopted by the administration following the CJEU pronouncements. ${ }^{93}$ Other national courts also rejected

\footnotetext{
${ }^{87}$ Case C-554/13 Zh and O ECLI:EU:C:2015:377.FJ.

${ }^{88}$ Mahdi (n 15).

${ }^{89}$ ibid, and Case C-357/09 PPU, Kadzoev, ECLI:EU:C:2009:741 and Proposed EU Return Directive, A6-0339/2007, 20.09.2007, Amendment 19, Art 3.

${ }^{90}$ See, for instance, the judgments of Slovakian courts, eg judgment 9 Sp 99/2013, see also the REDIAL Slovakian Report on Pre-Removal Detention, third package; see also the Dutch Council of State follow-up judgment to the CJEU preliminary ruling in Zh and O (at Raad Van State, 201407197/ 1/V3, 20 November 2015), which is commented in REDIAL Research Report 2016/02 (n 39) 10.

${ }^{91}$ No A-3219-858/2015, judgment of 22 July 2015.

${ }^{92}$ Supreme Migration Court (Sweden), case no MIG 2008:23 UM1610-08. The justification provided by this court was that the detention order would no longer be a last-resort measure, if refusal of voluntary departure would automatically be considered a risk of absconding, but it would be ordered in the majority of cases involving refused asylum seekers. See more in the T Quintel, REDIAL Swedish Report on Pre-Removal Detention, available at http://euredial.eu/docs/publications/national-synthesisreports/SwedenFB.pdf.

${ }^{93}$ TA Lille, 22 July 2011, no 1104137; CAA Bordeaux, 3 April 2012, No. 11CX02996; Dutch Council of State, 10 July 2014, 201309038/1/V1; CAA Paris, 1 ch, May 310, 2013, no 12PA03323.
} 
general statements deprived of concrete factual references to individual situations ('there is no integration in Austrian society or legal order') used to justify the existence of a risk of absconding. ${ }^{94}$ The Council for Alien Law Litigation of Belgium (CALL) started to closely scrutinise the circumstances of return-related cases, finding different results depending on the concrete circumstances of the case. For instance, the absence of an official address in Belgium was considered sufficient proof of a risk of absconding, justifying a refusal to grant a voluntary departure ${ }^{95}$ In another case, CALL took a different decision, although the same objective criterion, lack of an official address in Belgium, was found applicable. The court suspended the order to leave the territory and ordered the Aliens Office to take into consideration the fact that the applicant lived in fact with his wife and two children, who resided legally in Belgium, and that this particular aspect spoke against a risk of absconding, unlike the previous case. ${ }^{96} \mathrm{~A}$ similar change in approach was registered in Bulgaria. Although the Supreme Administrative Court had rejected the use of lack of identity documents as an automatic ground for pre-removal detention and prolongation of detention, ${ }^{97}$ this judgment was widely endorsed only following the CJEU preliminary ruling in Mahdi. ${ }^{98}$ In conclusion, there seems to be an increasing jurisprudential trend whereby courts no longer accept as justified the automatic finding of the administration of a risk of absconding under the impact of vertical judicial dialogue. ${ }^{99}$

This chapter does not argue in favour of more harmonisation of objective criteria as a solution to ensure more consistent assessment of the risk of absconding. ${ }^{100}$ It argues that, first and foremost, efforts should concentrate on legislative and administrative adaptation to the red lines drawn by CJEU and domestic courts in terms of acceptable objective criteria and their assessment. Certain circumstances, such as illegal entry, stay and lack of identity documents, are difficult to maintain as objective, given the approach of the CJEU in its case-law on the risk to public policy and pre-removal detention. ${ }^{101}$ Other criteria (eg lack of financial resources

\footnotetext{
${ }^{94}$ Federal Administrative Court, G307 2009115-1/2E, 28.7.2014; see the REDIAL Austrian Report on Pre-Removal Detention.

${ }^{95}$ CALL, no 97 083, 13.02.2013.

${ }^{96} \mathrm{~A}$ family seems to be widely considered as a guarantee that there is no risk of absconding.

${ }^{97}$ The Supreme Administrative Court of Bulgaria concluded that Recitals 6 and 13 of the Preamble to the Return Directive require the authorities to take into account several factors when establishing a risk of absconding. Among these, the Court mentioned the duration of the person's residence in Bulgaria; the categories of vulnerable persons; the existence of proceedings under the Law on Asylum and Refugees or proceedings for the renewal of a residence permit or of another authorisation offering a right to stay; the family situation; and the existence of the person's family, cultural and social ties with his/her country of origin; see case no 13868/2010.

${ }^{98}$ See the REDIAL Bulgarian Report on Pre-Removal Detention, third package. For a detailed assessment of the CJEU preliminary ruling in Mahdi and its impact at domestic level, see M Moraru, 'REDIAL Electronic Journal on Judicial Interaction: Articles 15 to 18 of the Return Directive 2008/115', REDIAL Research Report 2017/01, 23.

${ }^{99}$ See, in particular, the approach of the Austrian, Czech and French courts.

${ }^{100} \mathrm{~A}$ harmonisation proposal is put forward by the EC Proposal for the recast of the Return Directive, 6; although this proposal is highly criticised, see $\mathrm{n} 23$.

${ }^{101}$ Zh and $O$ (n 87) para 50; Mahdi (n 15) paras 40, 72.
} 
and payment of large amounts of money to smugglers for the purpose of illegally entering the territory of Member States) seem irrelevant to the assessment of a risk of absconding. In these circumstances, the application of judicial individual assessment is not sufficient to remedy an incoherent legislative and administrative transposition of the risk of absconding; only legislative amendment can succeed. However, should harmonisation of objective criteria be followed at the EU level, three main rules should be followed. First, we should look at the common denominator of objective criteria provided across the EU Member States, instead of copy-pasting all the criteria ever provided in national legal acts. Secondly, it is necessary to ask if the criteria obtained via the common denominator method are in line with the jurisprudentially developed red lines of the CJEU. Thirdly, the remaining criteria should then be checked against normative standards, such as respect for fundamental rights and rule of law. Ultimately, an impact assessment should be carried out proving a causal correlation between a narrow or broad definition of the risk of absconding and the (in)effectiveness of returns. So far, the only proven correlation has been that between the lack of cooperation of third countries and the enforcement of returns. ${ }^{102}$

\section{Clarification of the Effects of the Risk of Absconding - The Jurisprudential Principle of Gradualism for Choosing the Correct Return Measure}

The margin of discretion recognised for the Member States by the Directive's broad definition of a risk of absconding was wrongly interpreted by the Member States not only in terms of the content and number of objective criteria, but also in terms of the effects the risk of absconding could have on the return procedure. Although the Return Directive sets out the risk of absconding as legal grounds for several return-related measures, ${ }^{103}$ some Member States continued to prioritise pre-removal detention when a risk of absconding was identified. This was due to the fact that, at the time of its adoption, the Return Directive introduced a different model of returning irregular migrants from most of the domestic regulatory frameworks that were increasingly focused on 'securitisation' and 'deterrence.' ${ }^{04}$

The preliminary reference procedure has contributed to the clarification of the order in which the return measures must be adopted in the overall return procedure, thus including also those measures that could be adopted on the basis of

\footnotetext{
${ }^{102}$ S Mananashvili, 'EU's Return Policy: Mission Accomplished in 2016? Reading Between the Lines of the Latest EUROSTAT Return Statistics', ICMPD Policy Brief, May 2017.

${ }^{103}$ ie voluntary departure with obligations; shortening of voluntary departure; refusal of voluntary departure and adoption of removal order; pre-removal detention.

${ }^{104}$ See, in particular, Spain, Cyprus, Italy, and France; see Chapters 1, 5, 13 and 14 in this volume.
} 


\section{Madalina Moraru}

a risk of absconding. Following the preliminary references sent by Italian and French courts, the CJEU developed the principle of gradualism when deciding which return measure to adopt. ${ }^{105}$ According to this jurisprudentially developed principle, once the return decision is issued, Member States should follow a mandatory order in the return procedure, starting from the least restrictive to the third-country national's freedom (voluntary departure), ${ }^{106}$ followed by physical enforcement of the return (removal), ${ }^{107}$ issue of an entry ban, ${ }^{108}$ and the last-resort return measure, which is also the most coercive - pre-removal detention. ${ }^{109}$ This settled mandatory sliding scale of return measures commences with voluntary return, and will allow only for a step-by-step intensification of coercion. ${ }^{110}$ This 'gradation' of return measures was based by the CJEU on the EU law principle of proportionality, which governs the entire return procedure. ${ }^{111}$ According to the principle of proportionality, both administrative and judicial authorities should always consider and prefer the least coercive measure available in each individual case, not least during the removal process. The CJEU jurisprudence clarified that the Directive's return model is based on novel and protective underlying principles, such as legal clarity (all irregular third-country nationals should be served with a return decision or their stay should be regularised); the principle of primacy of voluntary departure over forced return; pre-removal detention as a last resort; individual assessment of cases; and the principle of respecting non-refoulement, best interests of the child, family life and state of health when implementing the Directive. Following the clear pronouncement of the principle of gradualism by the CJEU, the Member States had to adopt systemic reforms of their 'expulsion' procedures, requiring changes of legal terms, definitions, order of measures, and most importantly of their 'securitisation' or 'criminalisation' approach to managing immigration. ${ }^{112}$ In some jurisdictions, the reform took as long as a decade to align with the Directive's underlying principles, ${ }^{113}$ while some Member States still have not achieved a correct transposition. ${ }^{114}$

Following the jurisprudentially developed principle of gradualism, national courts started to pay closer attention to these principles when deciding the effects of the risk of absconding; this involved: establishing voluntary departure with

\footnotetext{
${ }^{105}$ See El Dridi (n 86) paras 36-41; Case C-290/14 Celaj ECLI:EU:C:2015:640; Sagor (n 86); and Case C-329/11 Achughbabian ECLI:EU:C:2011:807.

${ }^{106}$ See Art 7 of the Return Directive.

${ }^{107}$ Art 8 of the Return Directive.

${ }^{108}$ Art 11 of the Return Directive.

${ }^{109}$ See, in particular, Art 15 of the Return Directive.

${ }^{110}$ According to Celaj (n 105); Sagor (n 86); Achughbabian (n 105); El Dridi (n 86).

${ }^{111}$ See El Dridi (n 86) para 41.

${ }^{112}$ See 2014 EC Evaluation of the Implementation of the Return Directive (n 8).

${ }^{113}$ See, for instance, the case of Spain, where the 'doctrine of fine' was effectively replaced with the removal order only in the summer of 2018. See Rotaeche (n 18).

${ }^{114}$ Mostly as regards the prioritisation of alternatives to pre-removal detention, see more in di Pascale (n 36); S Slama, 'Trois hautes juridictions nationales pour une directive: une interaction judiciaire en trompe l'oil', Chapter 14 in this volume; and S Sarolea, 'Detention of Migrants in Belgium and the Criminal Judge: A Lewis Carroll World', Chapter 11 in this volume.
} 
attached obligations; limiting the voluntary departure period; refusing voluntary departure; and adopting a removal order, or detention. ${ }^{115}$ They gradually started to scrutinise the failure of the administrative authorities to adequately assess the possibility of imposing one or more obligations as an alternative prior to adopting a coercive removal order, and quashing administrative decisions that did not respect this principle. ${ }^{116}$ Furthermore, national courts increasingly rejected general statements, such as 'there is no integration in the society or legal order', as legitimate grounds proving a risk of absconding. ${ }^{117}$

A particularly sensitive challenge in the implementation of the risk of absconding was the limited reviewing and remedial powers of national courts. Certain administrative courts could not consider facts beyond those brought by administrative authorities and parties, and could not establish a different return-related measure in the place of the measure incorrectly established by the administration. The CJEU preliminary ruling in Mahdi empowered national courts to run an accurate and in-depth individual assessment of facts and law in order to determine the extension of pre-removal detention. To that end, the judicial authority

must be able to take into account both the facts stated and the evidence adduced by the administrative authority and any observations that may be submitted by the thirdcountry national. Furthermore, that authority must be able to consider any other element that is relevant for its decision should it so deem necessary. ${ }^{118}$

The CJEU also empowered national courts to substitute the administrative decisions on prolongation of pre-removal detention with their own decisions 'or, as the case may be, the judicial authority which ordered the initial detention, and to take a decision on whether to order an alternative measure or the release of the third-country national concerned. ${ }^{119}$ The CJEU preliminary ruling in Mahdi was interpreted by national courts across the EU as an empowerment to run an in-depth assessment of the administrative decisions ordering a preremoval detention, and thus implicitly also a careful assessment of the risk of absconding. ${ }^{120}$ Judicial empowerment has spread also in the Netherlands, ${ }^{121}$ Cyprus $^{122}$ and Slovenia, ${ }^{123}$ where courts considered they have an EU law

\footnotetext{
${ }^{115}$ See REDIAL Research Report 2016/01 (n 7).

116 ibid.

${ }^{117}$ See eg Austrian Federal Administrative Court, G307 2009115-1/2E, 28.7.2014; for more jurisprudence see REDIAL Research Report 2016/01 (n 7) and REDIAL Research Report 2016/02 (n 39).

${ }^{118}$ See Mahdi (n 15) para 62.

119 ibid.

${ }^{120}$ For more analysis of the Mahdi judgment and its impact in Bulgaria, see the REDIAL Bulgarian Report on Pre-Removal Detention; more widely at the EU level, see REDIAL Research Report 2017/01 (n 98). See also V Ilareva, 'The Right to Be Heard - The Underestimated Condition for Effective Returns and Human Rights Consideration', Chapter 15, in this volume.

${ }^{121}$ Dutch Council of State, Decision no 201408655/1/V3; see more in G Cornelisse, REDIAL Dutch Report on pre-removal detention.

${ }^{122}$ Cyprus, Supreme Court, Re. the application of Vilma Galivan Marcelino, civil application no 169/2012, 14 December 2012. See more in REDIAL Research Report 2017/01 (n 98).

${ }^{123}$ Administrative Court of the Republic of Slovenia, I U 1102/2016, 29.7.2016.
} 
obligation to assess in full and also on the basis of ex officio evidence all aspects of pre-removal detention, including the requirements of the risk of absconding. Moreover, they also started to go beyond mere annulment of the administrative decisions and decide the appropriate alternatives in cases of errors in the risk of absconding assessment. ${ }^{124}$

It appears that, following an intensive vertical judicial dialogue with the CJEU, national courts are slowly accepting the idea of extending their judicial review beyond mere manifest error(s) committed by the national authorities when assessing the risk of absconding. Courts are increasingly approaching the principles of gradualism, individualism and proportionality as mandatory parameters of legality for the return measures adopted on the basis of the risk of absconding. While significant changes have occurred in the practice of the supreme courts of Bulgaria, Italy and Spain, there is still a long way to go before this practice is uniformly spread across courts from all levels of jurisdictions and EU countries. As pointed out by several of the authors in this volume, there is still considerable judicial resistance to this approach, which cannot be addressed solely by more harmonisation or vertical judicial dialogue, but requires transnational judicial interaction, particularly in the form of transnational trainings and exchanges. ${ }^{125}$

\section{Conclusions: Judicial Dialogue Strengthening the Rule of Law in the Implementation of the Risk of Absconding}

This chapter has shown the development of a worrying trend among domestic administrations, which has blurred the lines between irregularity and the risk of absconding, by way of automatically presuming a risk of absconding whenever a third-country national finds herself in a situation of an irregular legal status. The broad definition of the risk of absconding, its automatic use and its transposition in administrative acts that escape parliamentary scrutiny are illustrations of a still present administrative monopoly over return procedures. This administrative control becomes particularly troublesome when it undermines judicial independence, powers and legitimacy, and endangers fundamental rights and the rule of law as mandatory principles governing the implementation of the Return Directive. Various strategies have developed in an attempt to limit the judicial scrutiny of administrative decisions finding a risk of absconding, such as: allocating competences to a new category of non-professional, honorary judges without specialisation (eg in Italy, the giudice di pace); limiting powers of judicial

\footnotetext{
${ }^{124}$ For more details see the chapters in Part II of this volume.

${ }^{125}$ See, in particular, Kosar and Blisa (n 13) and B Zalar, 'Impact of Judicial Dialogue(s) on Development and Affirmation of the Right to Effective Legal Remedy from Articles 13 and 14 of the Return Directive', Chapter 16 in this volume.
} 
review of the most contentious return related measure - pre-removal detention (eg Bulgaria) or discrediting the judicial understanding of the return procedures (eg Italy, Hungary). ${ }^{126}$

In this context of power struggles to maintain return procedures as the prerogative of the administration, and thus resisting changes required by the Return Directive, ${ }^{127}$ the jurisprudence analysed in this chapter shows that judicial dialogue has contributed in three main ways to the interpretation and application of the risk of absconding across the EU. First, it has helped courts to fill gaps in the EU legal definition of the risk of absconding and thus ensure a coherent application transnationally. For instance, the Al Chodor judgment has had ripple effects across domestic jurisdictions, leading to legislative reforms defining the risk of absconding in return procedures in national laws or a legal provision of general application.

Secondly, judicial dialogue has contributed to a de facto narrowing of objective criteria on the basis of the systematic application of individual assessment and application by analogy of the CJEU preliminary rulings as regards return proceedings. For instance, illegal entry, stay and lack of identity documents are less accepted by domestic courts as objective criteria, in particular as grounds for pre-removal detention. Moreover, a criminal record cannot automatically lead to a risk of absconding, but has to be joined by proof of a genuine and present risk. ${ }^{128}$

Thirdly, vertical judicial dialogue has contributed to the coherent implementation of the risk of absconding at domestic level, following common jurisprudentially crafted principles, such as: derogations should be strictly interpreted; ${ }^{129}$ respect of fundamental rights should be ensured at all stages of return procedures; ${ }^{130}$ the principle of proportionality should be ensured; ${ }^{131}$ and any assessment relating to the risk of the person concerned absconding must be based on the individual examination of that person's case. ${ }^{132}$

In spite of these positive achievements of judicial dialogue, there still are a number of deficiencies as regards the definition of the risk of absconding in domestic legislation and its practical application by domestic administrations. Notably, the number and content of 'objective criteria' have mostly remained those existent before the entry into force of the Directive. ${ }^{133}$ On this issue, the approach

\footnotetext{
${ }^{126}$ See $n 20$.

${ }^{127}$ See, in particular the long transposition of the risk of absconding in legal provisions of general application, such as laws; or the still present illegal entry and stay as objective criteria for finding a risk of absconding (e.g. Italy and Netherlands).

${ }^{128} \mathrm{Zh}$ and $O$ (n 87) para 50.

${ }^{129}$ ibid, para 42.

${ }^{130}$ El Dridi (n 86).

${ }^{131}$ El Dridi (n 86), para 41.

132 Sagor (n 86), para 41; Mahdi (n 86) para 70.

${ }^{133}$ For instance Spain (see Chapter 1 in this volume), Netherlands (REDIAL National Synthesis Report on Termination of Illegal Stay (n 16) 2-4, available at http://euredial.eu/docs/publications/ national-synthesis-reports/NETHERLANDS.pdf), Slovenia (REDIAL Research Report 2016/01 (n 7) 17 et seq).
} 
taken by domestic courts has been quite conservative, as they did not address a preliminary reference to the CJEU asking for guidelines on how to interpret the requirement of 'objective criteria', nor disapplied national legislation providing numerous objective criteria that would revert the mandatory order of return stages set by the Directive. The lack of preliminary questions on the risk of absconding within return procedures could be the result of both conscious and unconscious judicial decisions. A lesser degree of EU law knowledge, a stronger orientation towards national law and deferential approach towards the decision-making of the administration may result in unawareness of certain incompatibilities or uncertainties at EU level. This orientation appears to be typical for the Italian giudice di pace, and to a certain extent of some of the French courts. On the other hand, the national courts' decision not to refer might be a conscious one in other countries. National judges may not refer preliminary questions as they feel quite competent to apply EU law themselves, relying on a vast body of case-law developed by the CJEU (eg Dutch courts using the individual assessment to narrow down the Dutch long list of objective criteria). In conclusion, this chapter argues that more efforts are needed from both domestic judiciaries and other state powers to remedy the domestic lists including numerous objective criteria, especially those originating from before the entry into force of the Directive, ${ }^{134}$ along the lines of the CJEU jurisprudence.

\footnotetext{
${ }^{134}$ See, in particular, Spain, according to Rotaeche (n 17).
} 